\title{
SO CLOSE YET SO FAR: DIVIDED CONTEXTS ON THE MEXICO-GUATEMALA BORDER
}

\author{
Luis Fernando Zapata Montalvo
}

De Montfort University, Leicester, UK, luis.zapatamontalvo@dmu.ac.uk

\section{RESUMEN}

La frontera entre México y Guatemala es el resultado de la confluencia geopolítica de dos países con prioridades diferentes, generando diferentes formas de organización en la vida de sus habitantes y de las personas que transitan por esta zona. Este contexto ha creado condiciones de interacción sobre lo que cada país considera legal, ilegal y punible, dando lugar a varias interpretaciones de los fenómenos migratorios. Son contextos reales que adoptan el tránsito de personas. Situaciones que son posibles y dan sentido a la vida de muchas personas en contextos divididos.

Este artículo presenta una visión general de dos lugares transfronterizos entre México y Guatemala que pretenden describir la zona fronteriza y la movilidad de las personas como un fenómeno social. ¿Qué motiva a las personas a moverse entre ambos países? y ¿cuáles son las relaciones y decisiones vinculadas a que alguien o algo pueda moverse y decida hacerlo? más aún cuando esta movilidad supone el cruce de una frontera delimitada políticamente, son algunas de las preguntas planteadas en este artículo.

Para responder a estas preguntas, realicé un enfoque cualitativo, que pretende lograr una mejor comprensión de la dinámica de las personas que viven en estos lugares.

Palabras clave: Guatemala, Frontera, México, Movilidad, migración

\section{ABSTRACT}

The border between Mexico and Guatemala results from the geopolitical confluence of two countries with different priorities, generating 
different ways of organization in the lives of its inhabitants and the people who transit through this zone. This context has created conditions of interaction on what each country consider legal, illegal and punishable, leading to several interpretations of the migratory phenomena. We are facing real contexts that adopt the transit of human beings. Situations that are possible and give meaning to the lives of many people in divided contexts.

This article presents an overview of two cross-border locations between Mexico and Guatemala that intend to describe the border zone and the mobility of people as a social phenomenon. What motivates people to move between both countries? and what are the relationships and decisions linked to someone or something being able to move and decide to do so? even more when this mobility means the crossing of a politically delimited border? are some of the questions raised in this article.

To respond to the questions raised, I carried out a qualitative approach, which will also allow achieving a better understanding of the dynamics of people who live in these places.

\section{Key words: Guatemala, Border, Mexico, Mo- bility, Migration}

\section{RESUMO}

A fronteira entre o México e a Guatemala é resultado da confluência geopolítica de dois países com prioridades diferentes, gerando diferentes formas de organização na vida dos seus habitantes e das pessoas que transitam por esta zona. Este contexto possibilitoua a criação de condições de interação distintas, naquilo que cada país considera legal, ilegal e punível, permitindo várias interpretações dos fenômenos migratórios. Estamos perante contextos reais de trânsito de seres humanos, situações possíveis que dão sentido à vida de muitas pessoas em contextos divididos.

Este artigo pretende descrever a zona fronteiriça e a mobilidade das pessoas como um fenómeno social, para tanto apresentando uma visão geral de dois locais transfronteiriços entre o México e a Guatemala. O que motiva as pessoas a moverem-se entre os dois países? quais são as relações e decisões vinculadas a que alguém ou algo possa mover-se e decida fazê-lo? ainda mais quando esta mobilidade significa a travessia de uma fronteira politicamente delimitada? Estas são algumas das questões levantadas neste artigo.

Para responder a estas questões, buscando compreender melhor a dinâmica das pessoas que vivem nestes locais, o texto desenvolve um enfoque qualitativo.

\section{Palavras-chave: Guatemala, Fronteira, Méxi- co, Mobilidade, Migração}

\section{INTRODUCTION}

In this article, I intend to describe the relationships set between people, objects and places by defining how eventual dynamics of reciprocity and trust guarantee an infinity of resources. It is about the resources created in the proper relations of these cross-borders. It is about territory with policies that have imagined and created maps of mobility, crime, jurisdiction, of government action. But also, above them, by 
them or against them, is about the people who circulate and inhabit the border.

The concept of frontier refers to several terms with different meanings: the concept as a border, the concept as frontier, and the concept as a boundary are the most studied by scholars. Juan de Vos approached the first two concepts analysing the historical and contemporary processes of the southern border of Mexico. (De Vos 1993, 312-318).

The concept of a border or borderland refers to the political and territorial delimitation between countries. In other words, a border divides and separates. The political meaning behind this concept is sometimes the result of historical agreements and, in some cases, a political conflict. Which, generally, is characterized by its permanence and immobility through the years. The border also refers to a process of colonization in the sense of a front that tends to progress. The concept is associated with successive processes of appropriation of the territory through human migration flows, occupation processes and, impacts on natural resources. Unlike the previous concept, it is a border that is transformed and modified over the years.

The border in the sense of "boundary" is related to the so-called "secondary borders" 1 as described by Michael Kearney in his work "Fronteras Fragmentadas, Fronteras Reforzadas" (Kearney 1999, 559-570), which has been

1 I am referring primarily to the borders which Michael Kearney in his essay calls "secondary": cultural, linguistic, religious, ethnic, and social boundaries. These are real and imaginary borders that are a constant reference in the life of millions of people living in both countries. Kearney, Michael. Fronteras fragmentadas, fronteras reforzadas, in Gail Mummert (editora), Fronteras fragmentadas, Morelia: El Colegio de Michoacán, CIDEM, 1999: 559-570. less studied in the context of the border between Mexico and Guatemala (Cruz 1998, 260; Kauffer 2005, 7-36). These boundaries refer to divisions between cultural, linguistic, religious, social and ethnic groups, conceptualized in "Ethnic Groups and Boundaries" (Barth 1969, 118-120) as dualities between "us", as common origin; and "they" as products of social interaction.

After more than two decades of systematic studies on the border shared between Mexico and Guatemala, this territorial space has gained notoriety within the academic field. However, worth noting is that the existing literature on this context shows four main limitations. The first is the predominance of a vision around this space as the so-called "southern border" ${ }^{2}$, which refers to the south seen from the Mexican territory perspective, excluding Guatemala's and Belize's perspectives for whom the common border corresponds to their " northern border." The "southern border" often refers to the Mexican states neighbouring Guatemala and Belize, favoured by a series of political, economic and territorial asymmetries, which leads to an academic hegemony.

In this context, researchers approach the "southern border" without being questioned for its exclusionary vision (Basail 2005, 118-120; Villafuerte 2004, 288), even if they recognize the need and relevance of the vision of the other side in a more cross-border perspective rather than a border perspective. Thus, the exceptions to this hegemonic vision are li-

2 Geopolitically, this border represents much of the western and northern boundary of the region of Central America within North America. It is across this border that most of the commerce between Mexico, Guatemala, Belize and the rest of Central America takes place. 
mited (Dardón 2002, 325-326; Kauffer 2005, 183; Vautrevers 2005, 60-65).

The second limitation of the current literature is characterized by a vision of the "southern border" centred almost exclusively on the political relationships between the Mexican state of Chiapas and Guatemala and, to a lesser extent, between the Mexican state Quintana Roo with Belize. This is mainly due to the existing unfinished border dynamics of the Mexican states of Campeche and Tabasco characterized by the migratory flows and trade relations that Castillo et al., attribute to the sparsely populated character of the Guatemala side, which does not contribute to the development of cross-border relationships. Nowadays, the vision of this border still does not extend in the totality of its large geographical territory (Castillo 2006, 23-27).

In the third limitation, while the social, political and economic phenomena around the border have become the subject of several studies, the historical conformation (De Vos 1993, 312-318) and the cultural dynamics that allow the establishment of ties on both sides is still underestimated (Cruz 1998, 262).

The fourth limitation is associated with the lack of definition of what the different authors understand about this border; whether it's a delimitation of administrative boundaries attached to the states, departments and districts, or if it is a geopolitical strip dividing both countries, characterized by geographical limitations (Castillo et al. 2006, 17-21; Fábregas 2005, 40-43). The political, legal, geographical and socio-cultural definitions of the border lead to different conceptualizations.

\section{BORDERS AS ITINERARIES, STATIONS AND DESTINATIONS}

The border between Mexico and Guatemala is an international boundary of approximately 965 kilometres in length located in Central America. On the Mexican side are the states of Chiapas (654 km), Tabasco (108 km) and Campeche $(194 \mathrm{~km})$. While in the part of Guatemala border are the departments of San Marcos, Huehuetenango, Quiché, and Petén.

The border of Mexico with Guatemala combines a variety of actors with different dynamics and interests built not only at the local level but also at national, regional and global scales. In this region, there is a large diversity of people who transit from one country to the other or at least, they attempt to do it for different purposes. Some people carry and transport all sorts of goods; There are also people who arrive at these points as part of their routes to distant destinations, often in the long journey to the United States. Others live in the towns and small villages near the border. For some people, mobility is the aim or a need, and it becomes the means to achieve different goals.

The international border crossings between Mexico and Guatemala have not changed much since the last few decades. They continue to be characterized by an intense mercantile exchange (legal, informal and illegal) and, at the same time by different degrees of conflict or tension, often evidenced in the context of the formal relationships of the population with the norms of each country through well-established geopolitical limits. This topic is approached in some studies carried out in the region, such as the research carried out by Carlos Ruiz and Germán Martínez on the Informal Cross- 
Border Trade between Mexico and Guatemala and the experience of the street vendors on both sides (Ruiz and Martínez 2015, 149-174.) Both authors deconstruct the concept of "double border" by analysing the political origin and the scenarios in this space of international confluence. Natalia Armijo addresses the conflicting relationships between traders who evade fiscal controls, the border police and customs, emphasizing the organizational aspects that enable trade while evidencing the consequences derived from the application of public control measures (Armijo 2011, 35-51).

Enrique Coraza de los Santos in his work Frontera Seguridad y Movilidades en el Espacio Transfronterizo México-Guatemala (Border Security and Mobility in the MexicoGuatemala Cross-Border Space) describes the reality of traders and the criminalizing interventions through government policies on the border with Mexico and Guatemala ${ }^{3}$ and points out that such policies are deployed to favour the expansion of capital (Coraza 2019, 40-48). In “Beyond the Centre and the Periphery: Mexico's Southern Border Under Debate from a Globalization Perspective", Haana Laako focuses on the mediatic discourse by highlighting the analysis of space, culture and the circulation of goods and people, emphasizing political, social, commercial, ethnic and religious aspects (Laako 2014, 5-18.).

3 Cross-border intermediaries, smugglers, and residents more tangentially involved in these enterprises struggle to earn a living and justify their choices in a local economy where contraband is a major facet of everyday life. Coraza de los Santos, Enrique. Frontera Seguridad y Movilidades en el Espacio Transfronterizo México-Guatemala, in Realidades de la Frontera Sur: Compendio de Colaboraciones de ECOSUR con el CEIGB, Centro de Estudios Internacionales Gilberto Bosques, Mexico, 2019: 40-48
Walther L. Bernecker observes and analyzes the everyday life of the border to create a geography of smuggling through local stories, highlighting the ways in which the figure of the smuggler emerges in the history of the border and discusses the relationship between the legal and the illegal of these practices (Bernecker 2005, 133-151).

Whether the dynamics at the border are related to commercial exchanges, state controls, uses of space and mobility or cultural configurations, it is evident that each place has its particular characteristics within a historical and cultural context. Being this, the dominant aspect of the above-mentioned research. The contributions cited demonstrates that the border is much more than a concept. It is an experience worth being further studied. The border set contrasts, creating variety in the possibilities of life, of association and protection.

We cannot think of borders without alluding to the concepts of environment, place, space, territory and mobility, which have become clear through anthropology, history and geography, progressively becoming analytical tools for the understanding of social and material life in various contexts (Santos 2001, 84-87).

In this sense, understanding life as a determinant of the context and the perception as the result of the synthesis of people living in integrated spheres of experience and meaning will allow us to understand life at the border. Thinking about the environment generated in the border between both countries allows going beyond the political-administrative separations that usually overlap the analysis of socio-spatial dynamics when thinking in terms of legal or illegal migrations. 
My first approach to the region occurred in 1998 when I worked for a Mexican Government department in charge of the maintenance works of offices at Mexico's border crossings and a few years later as an informal visitor. "The southern border" as it is often called on the Mexican side, is a very fertile area of lush vegetation, distant more than $1000 \mathrm{Kms}$ from the geopolitical "Centre" of Mexico and about $900 \mathrm{Kms}$ from the "Centre" of Guatemala.

The first and largest border crossing point I visited is located in Ciudad Hidalgo (Hidalgo City) in the Mexican State Chiapas and Tecún Umán in the San Marcos Department of Guatemala, which characterizes by a coastal strip that starts in the Pacific Ocean demarcated by the banks of the Suchiate River dividing both countries.

The economic life of Ciudad Hidalgo and Tecún Umán generally develops near the Suchiate River and in the central areas of both cities, where the trades exchange of goods takes place, both by customs regulatory guidelines and by crossings called in Spanish "caminos de extravío" (lost paths), which are mechanisms known locally as "ant trade" characterized by the smuggling of goods.
The frontier bridge over the Suchiate River that connects Ciudad Hidalgo and Tecún Umán named Dr. Rodolfo Robles is the land border crossing with the greatest commercial activity in the region (Rojas and Fletes 2017, 12-21). The Mexican facilities of the Tax Administration Service are located there and, approximately 300 meters away, is the "Suchiate II" bridge (the largest fiscal and commercial enclosure of the Mexican government on the border with Guatemala). In this same perimeter, on the river banks, there are at least three informal crossings (lost paths) named in Spanish as: "El Palenque", Los Rojos (The Reds) and Los Limones (The Lemons), which are small jetties for small rafts made of tractor tires and wooden beams that function as transport of both people and goods, in both directions (Fig.1). Which enjoy the implicit tolerance of local government workers and the social support of the population that lives and works there.

A diverse and stratified labour context has developed around this social dynamic, in which both Guatemalan and Mexican workers participate. They are a group of people of different ages, who carry out diverse activities from
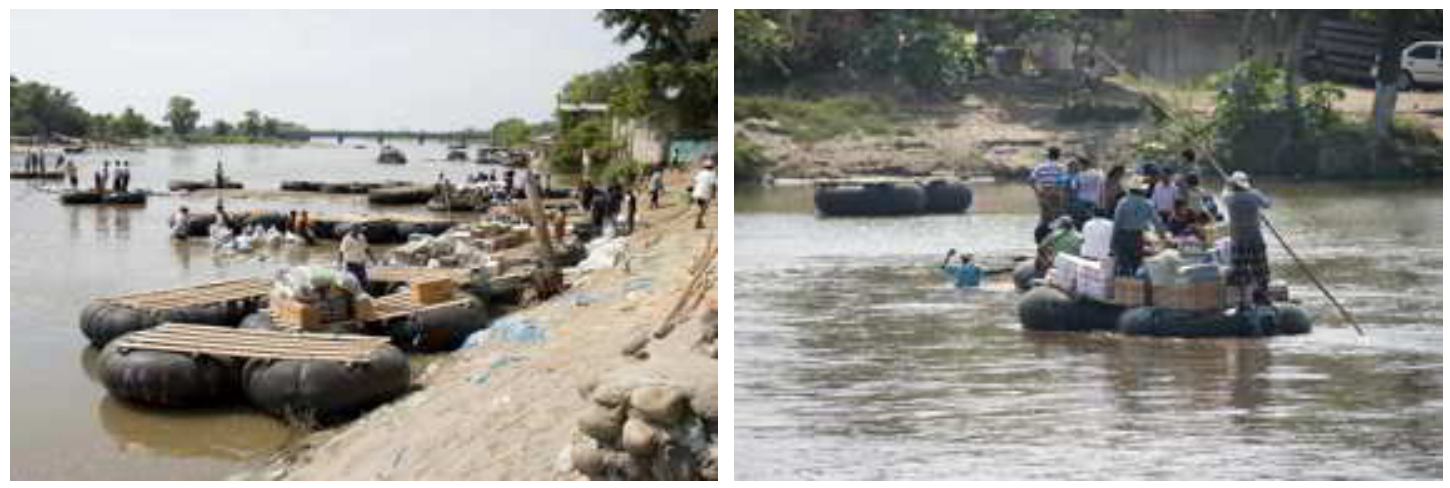

Figure 1 A crossing along the Suchiate River near the border cities of Ciudad Hidalgo in Mexico, and Tecún Umán, Guatemala. The rafts that cross the Suchiate River are made of wood planks lashed to inner tubes of tractor tires 
jobs that have a direct relationship with commerce through providers of public transport services such as rickshaws, illegal currency exchangers, customs agents and even the municipal police and the army, who tangentially or secondarily influence to shape and make possible these mobilities.

This social phenomenon evidences the porosity of a border full of contradictions, where the boundaries between legality and illegality are blurred. Under the bridge, migrants without economic means cross the border illegally by taking advantage of the "gaps" that the structures leave. In other words, the daily life at this border crossing is a clear example of the ways in which spaces are configured from the "cracks" of the "regulatory" system, which have historically allowed informal trade and the transnational labour movement to largely support the local economy in this area.

The second-largest border crossing is located between the towns Las Champas in the Mexican state of Chiapas and La Mesilla in the municipality of La Democracia in Huehuetenango, Guatemala. This border crossing began gaining importance in 2005 when Hurricane Stan damaged the train tracks at Ciudad Hidalgo (Arriola 2010, 169-188), which consequently led to the development of this new border as a referent of entry to Mexico and Guatemala.

In the division between the two towns, there are "welcome" signs indicating the border between the two countries, a division also represented by white boundary pillars placed along the borderline and which extends along the natural landscape (Fig. 2). With such contrasts, some more visible than others, both Las Champas and La Mesilla are commercial areas, in which it is possible to find a diversity of places that sell from handmade kitchen utensils, crafts, and blankets, to seasonal clothes, traditional garments and the popular "bale clothes" or "American second hand used clothing" that attracts buyers from different parts of Mexico. Similarly, on the Mexican side, there are grocery stores and automotive spare parts stores. In the trading days, people from both countries sell their products displayed in trading stalls fitted along the main streets that cross much of the towns.
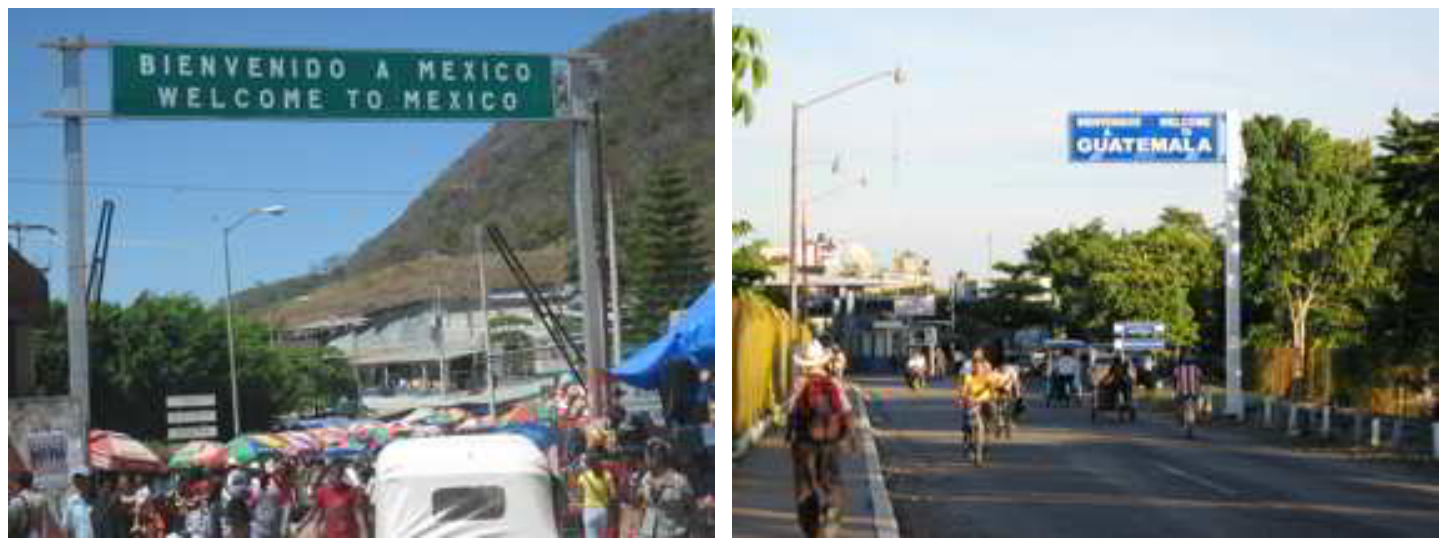

Figure 2 Entrance to Mexico in the Ciudad Hidalgo border crossing and entrance to Guatemala through the Tecun Uman border gates. In the division between the two towns, there are welcome signs. 

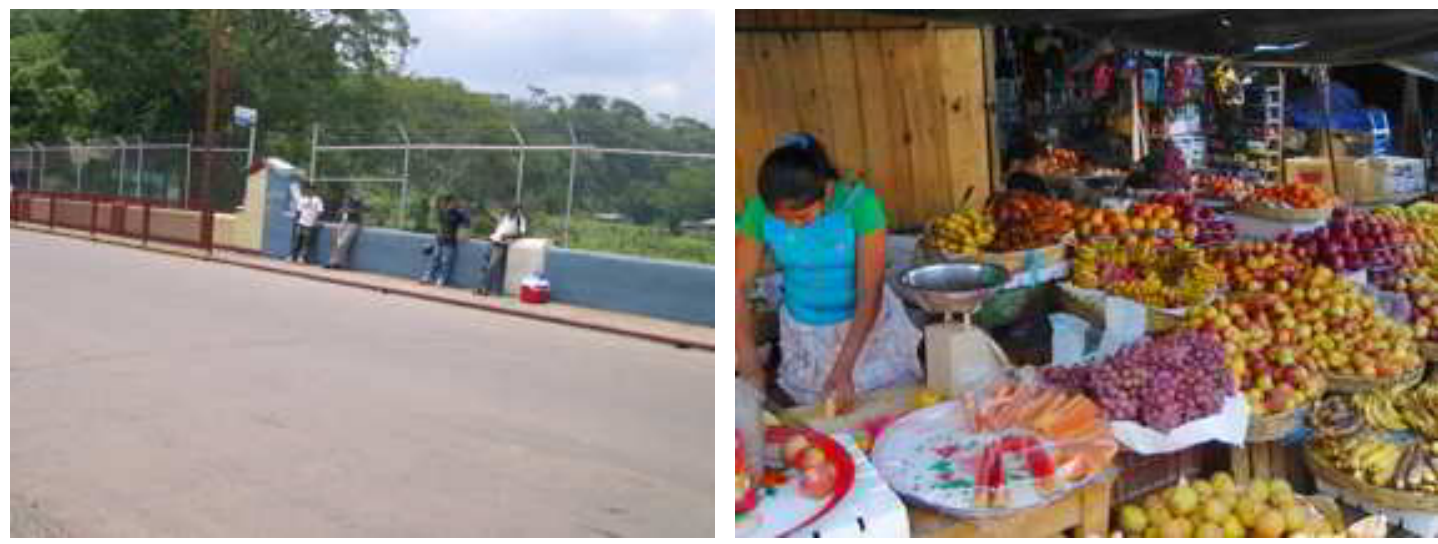

Figure 3 On both sides of the border it is notorious the presence of men who walk with bags or fanny packs tied at the waist who offer to exchange currencies from both countries. Families live from the sale of handicrafts and prepared foods.

It is also possible to observe some of the key actors that allow the dynamics of exchange between these two cities, for example, it is notorious the presence of men who walk with bags or fanny packs tied at the waist who offer to exchange Mexican pesos for Quetzales or vice versa (the so-called "money traders"). Some of them carry a gun to intimidate anyone who dares to rob them (Fig.3).

Here, as in the cross-border point that comprises Ciudad Hidalgo and Tecún Umán, people and mobility are intertwined beyond concepts of the formal and informal. The local economic dynamic is associated with this "flexible" way of understanding both terms because it is around it that the constant crossing of individuals is organized, giving life and sense to the border.

\section{AN OVERVIEW TO THE INTANGIBLE DIVIDED CONTEXT}

Several people informed me about this place as a region of rich ecological beauty with beauti- ful natural landscapes but also, as a hot zone of drug trafficking and smuggling for the whole border region between Mexico, Guatemala and Belize. This contrasting scenario becomes evident when one approaches any of these borders.

These divided contexts are made of life and circumstances with stories that are worth to be written. For example, those who arrive at the neighbouring towns at the border crossings may confuse a Guatemalan person for a Mexican person because of their way of speaking or their facial features. However, that resemblance would never confuse a local inhabitant.

The people who transit between Mexico and Guatemala use specific vocabularies, combining Spanish with the local language (Different variants of Mayan language), accentuating differences in their gesturing with variations in voice tones, mixing words in a particular way or structuring some phrases. The region condenses these aspects along the entire border between both countries.

In Ciudad Hidalgo, on the Mexican side border, some families live from the sale of handicrafts and prepared foods (fig.3). Very 
young women carry their children on their backs. They wait for someone to buy any of their products and usually walk on the main road or streets; they walk with heaviness, perhaps tired of the strenuous routine. Children often play in the dirt; they laugh, push each other and also sleep. Some locals say that to sleeping they must make great journeys to their distant communities. Others say they sleep on the street under any shade that shelters them. Some of these families are composed of women with children, but one rarely sees men where food stalls are because men perform different activities.

The movement of people in and across the border crossings is perhaps one of the most frequent features. But there are also migrants of African, Arab, Chinese and Indian origin dedicated to the trade of goods, who have diversified the population composition, surprising with their ability to adapt themselves in such ethnic diversity. For example, some Chinese migrants arrived in Mexico through acquaintances or friends who had already settled in Ciudad Hidalgo. They came speaking their language and slowly learned Spanish as a necessary instrument for their best performance in the trading area.

This phenomenon is surprising because some of these traders do not have basic studies. Despite the existing trade shocks that Mexico and Guatemala have been going through, especially on this border, their skills for trading have led to some favourable economic situations. These foreign migrants are men in general. Although some of them tend to maintain marriages with people of the same origin, they also marry Mexican or Guatemalan women creating mixed bonds of kinship.
The way people make their journeys and trace their itineraries challenge any national separations, the state-imposed divisions, and expectations of "stability" that could be assumed as the fundamental foundations for a settled life. However, somehow, there is a widespread idea that the mobility of people is associated with instability and vulnerability. Through my visits to the border, I gradually perceived that it could also be the opposite; moving from one place to another can guarantee people access to more resources.

These are journeys made through experiences lived in distant places, experiences reconfigured by cycles in the life of individuals or the lives of families who transit through these border locations. These intangible stories show us that the international border between Mexico and Guatemala is both a resource and a limitation. It expands within a life trajectory, reformulating or reducing cultural distances in the same process of setting the differences in the whole web of relationships that happen in the everyday.

In 2020, the border crossings were closed with the Covid-19 pandemic that placed many migrants in transit, asylum seekers and refugees in apparent immobility. Covid-19 put some migrants on pause on their journey to reach the north of Mexico to continue from there towards the United States. The lives of numerous migrants entered into a worrying phase of risks and vulnerabilities; dangers still abound while government responses are inappropriate and inconsistent with the realities of migrants. The crossing borders in the region are still closed and, their people are forgotten as some crossing borders do not have the means to safeguard their lives. The stories 
of many migrants face this conflict; they show feelings of incomprehension and desperation. Their voice and words reflect that tension and a loss of direction. At the moment, many people stranded, applicants or refugees in this space of the border ironically say that, in the waiting to continue towards the "American dream", they live in the meantime the "Mexican dream".

The realities of two regions geopolitically divided with images, people and practicalities continue to enter into play. To my surprise, what I initially looked at as two divided contexts barely coexisting in the same place, progressively showed themselves as a web of relationships, giving Mexico's southern border or Guatemala's northern border a meaning.

\section{LIVING IN THE BORDER IN MEXICO FROM THE MIGRANT PERSPECTIVE}

When looking closely at the border area and its people, it is possible to understand the different meanings of the migration experience. Gradually, some migrants have found various ways to live in this place; some of them sell traditional foods from their places of origin. Other people have barbershops located in the main streets, most of them are Hondurans who have lived in the United States and offer the latest cuts and hairstyles to fashion. There are also migrants from Haiti and Africa who recently settled. Afro-descendant women are commonly seated on the streets and offer combings (black or coloured braids), while men, who speak little Spanish, offer hairstyles through a sort of menu with photos showing different types of haircuts.
There is also the historical presence of Guatemalans who have been the labour force that enhanced the cities at the border crossings. They share past stories of the border division from times when their ancestors migrated as day labourers to cut coffee on plantations of German and Mexican owners who settled in the late 19th and early 20th centuries. Some workers stayed on the Mexican side border, were nationalized and maintained ties with their places of origin beyond the border. At present, cross-border work remains, but there is less demand for day labourers due to the coffee crisis and the decline of some coffee plantations. In the bigger cities and other surrounding municipalities, Guatemalan women work in the homes of local people as domestic workers, and some of them cross the border daily to reach their jobs.

The bars are part of the daily life of this border municipality, which has a hot and humid climate all year round. Some women work as escorts, who accompany customers while drinking beer and listening to music; others are sex workers in some areas in the city centre or nearby bars. On the other hand, some Salvadorans and Hondurans work as security guards in these same spaces, Haitians have recently been employed in construction works, and some $\mathrm{Cu}$ bans work as waiters in restaurants.

Housing spaces have also diversified. Many Salvadorans, Hondurans and Guatemalans rent houses in some neighbourhoods, which are located on the city outskirts and are known by local inhabitants as the small spaces where migrants or "Central Americans" are. Some Haitian families settled in neighbourhoods considered marginalized or irregular by the municipal government; others found cheaper, comfortable, but secluded spaces. 
The stories of many migrants allow us to comprehend the characteristics of their journeys, their emotions and their experiences. It seems that the experience of this "silent expulsion" from their places of origin is always recalled. However, the border opens up opportunities to build a concrete and social life in a culture that is not their own, but that in turn, is no longer strange to them. "In the border, there are good and bad people," say several Central American migrants. The experience of mobility becomes an "imagined" and "lived" territory before and during the staying in it. It is in these border spaces where diverse and sometimes divergent imaginaries are put into play around migrants.

\section{CONCLUSIONS}

The fact that people divide the borders, cross or evade them, does not mean that they dissolve them neither that these have no meaning in their lives. The Mexico-Guatemala border is there as the result of many years of political processes. Borders are privileged places for the staging of the law. There, the limits of the sovereignty of a national state are materialized and symbolized in different things and actions.

The law at the border crossings is visible everywhere, in the customs offices, on walls, on signs announcing the end and the beginning of a territory or through warnings on the prosecution of certain types of crimes. There are barriers, fences, walls, queues, documents, offices, flags, border patrols, authorities, languages, people, boxes, handicrafts, vehicles, goods from both countries and in all sorts of forms of expression. Authority is a realm felt in the people who move between both sides of the border. It is a central or marginal reality lived mainly by those who settled near these borders, living with the law often seen as a threat but assuming risk margins upon it.

The stories shared in this article differentiate from each other in how movements, relationships and networks have been stablished through several activities that take place in the border between two countries. Each person lives the border as an experience of relationships capable of going beyond customs and border controls that become just one aspect of the whole that happens in these spaces. Although the concept of mobility allows encompassing the diversity of movements, I believe that describing what these consist of and how unpredictable they can be will give us elements to think about their materialization.

People's life routines show that the relationships they establish with each other reformulate the broad categories that sustain the legitimacy of the border as a universal reference. In every going and coming and every creative repetition of their journeys, we see the density of the woof that people and things weave, overlapping the two regions, the two countries, the two customs, the two states, through friendship, sense of neighbourhood and kinship.

By writing about shared experiences and places from the border of Mexico and Guatemala, I intend to contribute from an ethnographical perspective to studies carried out on this border, with sight on those actors who live it every day, observing how the movements create territories through the relationships between people and with things and their consequences. 
Rather than seeing fixed spaces in descriptive places, we can see the flow of people and things through space and their meaning in terms of subsistence, interest, coincidence and condition. Some of the experiences described in this article invite to see that the border may be beyond the state controls in a region of in-

\section{REFERENCES}

Armijo, Natalia. 2011. Frontera sur de México: los retos múltiples de la diversidad, in Migración y seguridad: nuevo desafí en México. El Colegio de México. Seminario sobre Violencia y Paz, 35-51.

Arriola Vega, Luis Alfredo. 2010. “Reconfiguración de la frontera Tabasco-Petén y migración al inicio del siglo XII." Migraciones contemporáneas. La región sur-sureste de México, editado por H. Ángeles Cruz, M. Ortíz Gabriel, M. Rojas Wiesner and D. Ramos Pioquinto. Colegio de la Frontera Sur (ECOSUR). Mexico: 169-188.

Barth, Fredrik. 1969. Ethnics Groups and Boundaries. The Social Organization of Culture Difference. Bergen: Oslo, Universitetsforlaget.

Basail, Alain. 2005. Fronteras des-bordadas. Ensayo sobre la frontera sur de México. México: Casa Juan Pablos, Universidad de Ciencias y Artes de Chiapas, 118-120.

Bernecker, Walther. 2005. "La principal industria del país: contrabando en el México decimonónico." América Latina en la Historia Económica, n.24: 133-151. ternational boundaries, and even discuss with them as it becomes a diversified resource. We can perceive the distance created between these images and what happens in the living space where people and things exist, move, are, hide, are created and also disappear. Places that seem distant, but at the same time are close.

Castillo, Manuel, Toussaint Mónica and Vázquez Mario. 2006. Espacios diversos, historia en común, México, Guatemala y Belice, La construcción de una frontera. México: Secretaría de Relaciones Exteriores, 23-27.

Coraza de los Santos, Enrique. 2019. "Frontera Seguridad y Movilidades en el Espacio Transfronterizo México-Guatemala." Realidades de la Frontera Sur: Compendio de Colaboraciones de ECOSUR con el CEIGB, Centro de Estudios Internacionales Gilberto Bosques, Mexico: 40-48.

Cruz, Jorge. 1998. Identidades en fronteras, fronteras de identidades. Elogio de la intensidad de los tiempos en los pueblos de la frontera sur. México: El Colegio de México, 260.

Dardón, Jacobo. 2002. Caracterización de la frontera de Guatemala/México. Editorial de Ciencias Sociales, Facultad Latinoamericana de Ciencias Sociales. Guatemala, 325-326.

De Vos, Jan. 1993. Las fronteras de la frontera sur. Reseña de los proyectos de expansión que figuraron la frontera entre México y Centroamérica. México: Universidad Juárez Autónoma de Tabasco, Centro de Investigaciones y Estudios Superiores en Antropología Social, 312-318. 
De Vos, Jan. 2002. "Las fronteras de la frontera sur. Una visión histórica." Identidades, migraciones y género en la frontera sur de México, México editado por Edith F. Kauffer Michel. El Colegio de la Frontera Sur: 49-67.

Fábregas Puig, Andrés. 2005. "El concepto de frontera: una formulación." Fronteras des-bordadas. Ensayo sobre la frontera sur de México editado por Alain Basail Rodríguez. México: Casa Juan Pablos, Universidad de Ciencias y Artes de Chiapas: 21-51.

Kauffer Michel, Edith Françoise. 2005. “De la frontera política a las fronteras étnicas: refugiados guatemaltecos en México." Frontera Norte, 34: 7-36.

Kauffer Michel, Edith Françoise. 2002. Identidades, migraciones y género en la frontera sur de México. México: El Colegio de la Frontera Sur, 270.

Kauffer Michel, Edith Françoise. 2005. El agua en la frontera México-Guatemala, Belice. México: El Colegio de la Frontera Sur, UNACH, RISAF, TNC, The David and Lucile Packard Foundation, 183.

Kearney, Michael. 1999. "Fronteras fragmentadas, fronteras reforzadas." Fronteras fragmentadas, editado por Gail Mummert. Morelia: El Colegio de Michoacán, CIDEM: 559-570.
Laako, Haana. 2014. "Beyond the Center and the Periphery: Mexico's Southern Border Under Debate from a Globalization Perspective." Revista Pueblos y Frontera Digital, vol.9, 18: 5-18.

Rojas, Hugo and Fletes, Héctor. 2017. Configuración regional del Estado: Orden mercantil y comunidad interpretativa en la frontera México-Guatemala. Estudios fronterizos, 18 (35), 12-21.

Ruiz, Carlos and Martínez Germán. 2015. "Informal transborder trade between México and Guatemala from a Permissive Border Perspective." Estudios Fronterizos, Revista de Ciencias Sociales y Humanidades, Vol.16, 31, Universidad Autónoma de Baja California, Mexicali: 149-174.

Santos, Milton. 2001. La Naturaleza del Espacio, in Técnica y Tiempo, Razón y Emoción. Editorial Ariel. São Paulo, 84-87.

Vautrevers, Guadalupe. 2005. Estudio comparativo de la frontera Tabasco, México-El Petén, Guatemala, Villahermosa. Universidad Juárez Autónoma de Tabasco, 60-65.

Villafuerte, Daniel. 2004. La frontera sur de México. Del TLC México-Centroamérica al Plan Puebla-Panamá. México: Universidad Nacional Autónoma de México, Plaza y Valdés, 288.
Luis Fernando Zapata Montalvo $\mathrm{PhD}$ and Senior Lecturer at the Leicester School of Architecture. In the course of his practice experience he has developed advanced skills in architectural design and construction of residential, commercial, industrial and public buildings working in several architectural projects as a freelance architect and in architecture firms. Dr. Zapata was lecturer in architecture and construction technology at the University of 
the Valley of Mexico and the School of Architecture, Monterrey Institute of Technology and Higher Education in Mexico City, Mexico, where he was architecture program director. $\mathrm{He}$ also worked as tutor and lecturer in architecture and construction technology and management at the University of Melbourne and at Deakin University in Australia.

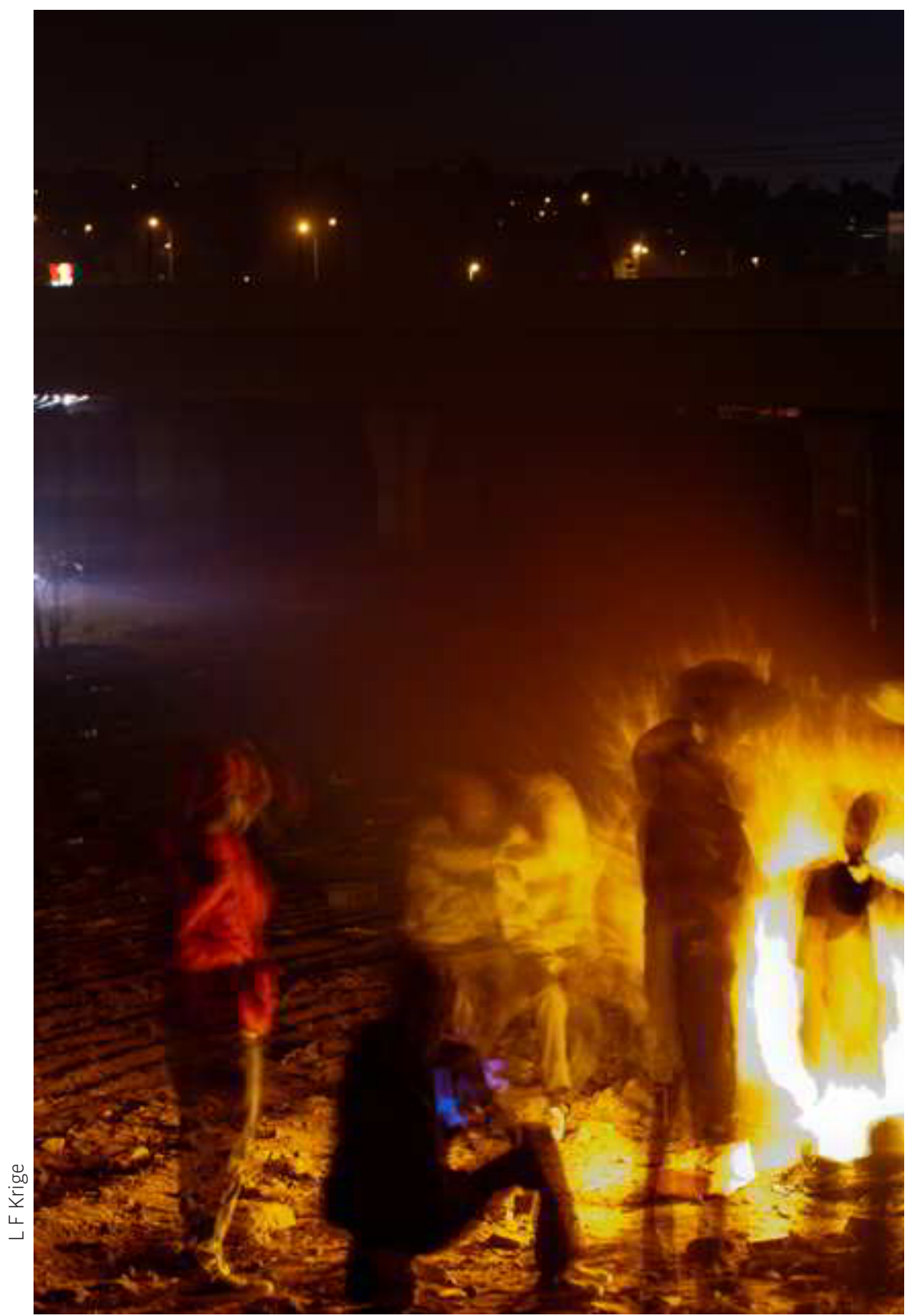

246 || ASTRAGALO No 29 | Diciembre, December, Dezembro 2021 | Article | ISSN 2469-0503 